\title{
PENGGUNAAN TENAGA KERJA LOKAL DALAM KONTEKS ESPANSI PT.TELKOM INDONESIA, TBK DI TIMOR LESTE DITINJAU DARI PERSPEKTIF PERBANDINGAN HUKUM KETENAGAKERJAAN
}

\author{
Elisabeth Anna Kanahebi \\ Program Studi Magister Ilmu Hukum \\ Universitas Nusa Cendana Kupang \\ Email: ellys_khan@yahoo.com
}

\begin{abstract}
The aim of this study are to know about the pattern of legal protection of outsourcing system for the local workers of TELIN in Timor Leste; the principle of balance and freedom of contract in the standard contractual agreements in the field of employment according to the labor laws of Indonesia and Timor Leste and to know about the law which is applied in cases in TELIN. The methodology of this research in normative legal. The results of this research are the outsourcing system does not provide legal protection for local workers of TELIN; there is no principle of balance and freedom of contract; and the dispute settlement patterns in TELIN are non litigation through arbitration.
\end{abstract}

Keywords: Local Workers; Outsourcing; Camparison Of Labour Laws

\begin{abstract}
Abstrak
Penelitian bertujuan untuk mengetahui pola perlindungan hukum sistem oustsourcing bagi tenaga kerja lokal yang bekerja pada TELIN di Timor Leste; implementasi asas keseimbangan dan kebebasan berkontrak dalam perjanjian kontrak standar di bidang ketenagakerjaan menurut Hukum ketenagakerjaan Indonesia dan Timor Leste dan hukum yang berlaku jika terjadi sengketa di bidang ketenagakerjaan pada TELIN di Timor Leste. Penelitian ini adalah penelitian yuridis normatif. Hasil penelitian menunjukkan bahwa belum ada perlindungan hukum secara memadai terhadap para pekerja lokal yang bekerja pada TELIN di Timor Leste; tidak ada asas keseimbangan dalam asas kebebasan berkontrak dan pola penyelesaian perselisihan perburuhan pada TELIN melalui arbitrase.
\end{abstract}

Kata kunci: Tenaga Kerja Lokal; Outsourcing; Perbandingan Hukum Ketenagakerjaan

\section{A. Pendahuluan}

1. Latar belakang Permasalahan

Sebagai Badan Usaha Milik Negara (BUMN) Telkom mempunyai 3 tugas yaitu menjaga kedaulatan Negara Kesatuan Republik Indonesia (NKRI), sebagai mesin pertumbuhan dan pemimpin daerah (engine of growth dan leader di regional). Tugas ini kemudian diterjemahkan ke dalam 3E yakni keberadaan bangsa, mesin pertumbuhan \& menjadi unggul dikawasan (existence of nation, engine of growth \& emperor of region) guna menjadi unggul di kawasan (emperor of region) Telkom berupaya melakukan International Expansion. Salah satu bentuk international expansion ini, Telkom melalui anak perusahan Telekomunikasi Indonesia
International hadir di Timor Leste yang dikenal dengan nama TELIN.

Atas dasar itu maka TELIN Timor Leste berupaya untuk menggunakan tenaga kerja lokal. Tenaga kerja lokal yang dimaksudkan disini adalah orang-orang Timor Leste yang dipekerjakan di TELIN Timor Leste. Namun, perbedaan ketentuan hukum Timor Leste dan Indonesia di bidang ketenagakerjaan merupakan persoalan tersendiri berkaitan dengan keberadaan tenaga kerja tersebut. Secara normatif, antara Indonesia dan Timor Leste mempunyai perbedaan esensial berkaitan dengan aspek perlindungan tenaga kerja. Poros utama perlindungan tenaga kerja di Negara Timor Leste adalah UU No. 4 Tahun 2012 Tentang

1. Artikel ini merupakan hasil penelitian 
Ketenagakerjaan. Sementara di Indonesia, menggunakan UU No.13 Tahun 2003 Tentang Ketenagakerjaan.

Perlindungan hukum dalam bidang ketenagakerjaan, seharusnya dimulai dari perekrutan yang meliputi pelatihan tenaga kerja sampai dengan pemutusan kontrak kerja termasuk di dalamnya bila terjadi sengketa ketenagakerjaan. Sementara UU No.4 Tahun 2012 hanya mengatur ketentuan yang bersifat umum. Belum adanya pengaturan khusus secara normatif berkaitan dengan aspek kesejahteraan tenaga kerja serta sanksi dalam UU No. 4 Tahun 2012 di Timor Leste, memberikan dampak belum adanya jaminan kepastian hukum terhadap perlindungan serta kesejahteraan tenaga kerja lokal di Timor Leste.

Terkait aspek hukum, jika sewaktuwaktu terjadi sengketa ketenagakerjaan pada TELIN, apakah menggunakan hukum Indonesia, ataukah menggunakan hukum Timor Leste, mengingat TELIN melakukan bisnis di negara Timor Leste yang kemudian mempekerjakan warga lokal di negara itu. Bisa saja pilihan hukum penyelesaian sengketa dapat dilakukan di luar dari kedua negara melalui lembaga Arbitrase, tergantung isi perjanjian yang dibuat para pihak.

Menjadi masalah serius ketika terjadi sengketa misalnya pemutusan kontrak kerja oleh TELIN. Untuk itu masing-masing pihak pasti mempertahankan sistem hukum masing-masing misalnya Timor Leste akan bersikeras dengan penggunaan aturannya, sementara TELIN akan tetap dengan regulasi bawaan yang dimilikinya. Persoalan yang seperti inilah yang akan memberikan ruang bagi pihak lain untuk merusak hubungan kerja antara Indonesia dan Timor Leste terkait dengan bidang usaha yang ada.

Fokus kajian penelitian ini perbandingan hukum dan aspek outsourcing, karena berkaitan dengan ekspansi PT Telkom ke berbagai negara. Akibat adanya sistem hukum yang berbeda, ketentuan yang tumpang tindih di bidang ketenagakerjaan, belum adanya jaminan kepastian hukum bagi tenaga kerja lokal dan belum adanya gambaran yang menjelaskan perlindungan hukum bagi tenaga kerja lokal pada TELIN di Timor Leste. Penelitian ini juga mengkaji prinsip persamaan dalam asas kebebasan berkontrak di PT TELIN. Permasalahan dalam penelitian ini meliputi 1). Bagaimanakah pola perlindungan hukum (sistem oustsourcing) bagi tenaga kerja lokal yang bekerja pada TELIN di negara Timor Leste berdasarkan hukum ketenagakerjaan kedua negara? 2). Bagaimanakah asas keseimbangan dan asas kebebasan berkontrak dalam perjanjian kontrak standar di bidang ketenagakerjaan menurut hukum ketenagakerjaan Indonesia dan Timor Leste? 3). Hukum manakah yang berlaku jika terjadi sengketa di bidang ketenagakerjaan pada TELIN di Timor Leste?

\section{Metode Penelitian}

Penelitian ini adalah penelitian yuridis normatif untuk mengkaji asas-asas, kaidahkaidah atau norma dalam hukum positif, terutama berkaitan dengan penggunaan tenaga kerja lokal oleh PT Telkom Indonesia di Timor Leste. Pendekatan yang digunakan untuk memecahkan masalah adalah pendekatan perundang-undangan (statute approach), pendekatan konsep (conceptual approach) dan pendekatan sistim hukum (systematical approach).

Sehubungan dengan hal tersebut, maka aspek-aspek yang diteliti dalam penelitian ini meliputi pola perlindungan hukum terhadap sistim outsourcing bagi tenaga kerja lokal yang bekerja pada TELIN Timor Leste, yang termuat di dalam undang undang Ketenagakerjaan Timor Leste maupun ketentuan Hukum Indonesia; asas keseimbangan dalam asas kebebasan berkontrak dalam bidang ketenagakerjaan menurut Hukum Ketenagakerjaan Indonesia dan Timor leste; dan pola penyelesaian sengketa terhadap permasalahan perburuhan menurut hukum Indonesia dan Timor Leste.

\section{Kerangka Teori}

Perjanjian adalah suatu hal yang penting karena menyangkut kepentingan para pihak yang membuatnya. Pasal 1313 KUH Perdata memberikan defenisi perjanjian sebagai "suatu perbuatan dengan mana satu orang atau lebih mengikatkan dirinya terhadap satu orang lain atau lebih. Menurut R. Setiawan, rumusan Pasal 1313 KUH Perdata tersebut kurang lengkap, perumusan perjanjian adalah suatu perbuatan hukum, dimana satu orang atau lebih, saling 
mengikatkan dirinya terhadap satu orang atau lebih. $^{2}$

Menurut Munir Fuady, asas kebebasan berkontrak memberikan kebebasan kepada para pihak untuk membuat atau tidak membuat kontrak, demikian juga kebebasan untuk mengatur sendiri isi kontrak tersebut. Asas ini tersirat dalam Pasal $1338 \mathrm{KUH}$ Perdata, pada intinya menyatakan bahwa terdapat kebebasan membuat kontrak apapun sejauh tidak bertentangan dengan hukum, ketertiban dan kesusilaan. Subekti menyatakan bahwa orang leluasa untuk membuat perjanjian apa saja, asal tidak melanggar ketertiban umum atau kesusilaan, p a d a u u m n a jug a bole h mengenyampingkan peraturan-peraturan yang termuat dalam Buku III karena Buku III merupakan "hukum pelengkap" (aanvullend recht) bukan hukum keras atau hukum yang memaksa. ${ }^{4}$

Selain itu terdapat asas lain seperti asas mengikat dalam suatu undang-undang, dimana di dalamnya mengandung prinsip Pacta Sun Servanda, bahwa perjanjian mengikat pihak-pihak yang mengadakannya atau setiap perjanjian harus ditaati dan ditepati. ${ }^{5}$ Sementara itu asas konsensualitas, sebagaimana yang tersirat dalam Pasal 1320 KUH Perdata, bahwa sebuah kontrak sudah terjadi dan karenanya mengikat para pihak dalam kontrak sejak terjadi kata sepakat tentang unsur pokok dari kontrak tersebut. Atau dengan perkataan lain, kontrak sudah sah apabila sudah tercapai kesepakatan mengenai unsur pokok kontrak dan tidak diperlukan formalitas tertentu. J.Satrio sebagaimana dikutip oleh RM Panggabean menulis bahwa seseorang dikatakan memberikan persetujuannya atau kesepakatannya (toestemming) jika seseorang tersebut memang menghendaki apa yang disepakati. ${ }^{6}$
Asas lain yang juga penting adalah asas itikad baik dimana Pasal 1338 ayat (3) KUHPerdata, menyatakan persetujuanpersetujuan harus dilaksanakan denganp itikad baik. Akan tetapi dalam pasal tersebut tidak disebutkan secara ekplisit apa yang dimaksud dengan "itikad baik". Akibatnya orang menemui kesulitan dalam menafsirkan arti dari itikad baik itu sendiri. Sementara itu, tentang perjanjian kerja diatur di dalam Bab IX UU No. 13 Tahun 2003. Pasal 1 angka (14) menyatakan bahwa perjanjian kerja adalah perjanjian antara pekerja/buruh dengan pengusaha atau pemberi kerja yang menurut menurut syarat-syarat kerja, hak dan kewajiban dari para pihak.

Menurut Tibor Kremic, et al, pengertian outsourcing dinyatakan sebagai berikut: "outsourcing is a common practice among both private and public organizations and is a major element in business strategy"? Outsourcing merupakan pendelegasian operasi dan manajemen harian dari suatu proses bisnis kepada pihak luar (perusahaan penyedia jasa outsourcing). Melalui pendelegasian itu, pengelolaan tak lagi dilakukan oleh perusahaan melainkan dilimpahkan kepada perusahaan jasa outsourcing. ${ }^{8}$

Mengenai pengupahan yang diatur dalam UU No. 13 Tahun 2003 bersifat hukum publik seperti PP No. 8 Tahun 1981 tentang Perlindungan Upah. Hal ini dapat diketahui dari ketentuan Pasal 95 ayat (3) yang menyatakan bahwa pemerintah mengatur pengenaan denda kepada pengusaha dan/atau pekerja/buruh dalam pembayaran upah. Adapun kewajiban pokok pengusaha selain membayar upah adalah juga mengatur tempat kerja dan alat kerja, memberi istirahat dan hari libur resmi, memberi surat keterangan serta bertindak sebagai pengusaha yang baik. Setiap pengusaha juga wajib untuk

2. R. Setiawan, 2003, Pokok Pokok Hukum Perikatan, Bandung, Bina Cipta, hlm. 49.

3. Munir Fuady, 2002, Pengantar Hukum Bisnis, Bandung, Citra Aditya Bakti, hlm. 12.

4. R. Subekti, 2005, Pokok-Pokok Hukum Perdata, Jakarta, Intermasa, hlm. 128.

5. C.S.T. Kansil, 1983, Pengantar Hukum Dan Tata Hukum Indonesia, Jakarta, Balai Pustaka, hlm.48.

6. RM Panggabean, "Keabsahan Perjanjian dengan Klausul Baku", Jurnal Hukum, Vol. 17, No. 4, Oktober 2010, pp. $651-667, \mathrm{hlm} 655$.

7. Tibor Kremic, Oya Icmeli Tukel and Walter O. Rom, "Outsourcing Decision Support: A Survey Of Benefits, Risks, And Decision Factors", Research paper, Supply Chain Management: An International Journal, Vol. 11, · No. 6 , 2006,pp. 467-482, hlm 467.

8. Sehat Damanik, 2006, Outsourcing \& Perjanjian Kerja, Jakarta, DSS Publishing, hlm. 2. 
menerangkan sistem manajemen keselamatan dan kesehatan kerja yang terintegrasi dengan sistim manajemen perusahaan.

Sistim manajemen keselamatan dan kesehatan kerja adalah bagian dari sistem manajemen perusahaan secara keseluruhan yang meliputi strukur organisasi, perencanaan, pelaksanaan, tanggung jawab, prosedur, proses dan sumber daya yang dibutuhkan. Hal ini diperlukan bagi pengembangan, penerapan, pencapaian, pengkajian dan pemeliharaan kebijakan keselamatan dan kesehatan kerja dalam pengendalian resiko yang berkaitan dengan kegiatan kerja guna terciptanya tempat kerja yang aman, efisien dan produktif. Sementara itu, setiap pekerja/buruh memperoleh penghasilan yang memenuhi penghidupan yang layak bagi kemanusiaan, yaitu sejumlah penerimaan atau pendapatan pekerja/buruh dan keluarganya secara wajar yang meliputi makanan dan minuman, sandang, pangan, pendidikan, kesehatan, rekreasi dan jaminan hari tua.

Pasal 86 UU No.13 Tahun 2003 menyebutkan bahwa setiap buruh mempunyai hak memperoleh perlindungan atas; kesehatan dan keselamatan kerja, moral dan kesusilaan, serta perlakuan yang sesuai dengan harkat dan martabat manusia serta nilai-nilai agama. Untuk melaksanakan hal tersebut di atas diselenggarakan upaya keselamatan dan kesehatan kerja yang dimaksudkan untuk memberikan jaminan keselamatan dan meningkatkan derajat kesehatan para pekerja dengan cara pencegahan kecelakaan dan penyakit akibat kerja, pengendalian bahaya di tempat kerja, promisi kesehatan dan rehabilitasi.

\section{B. Hasil dan Pembahasan}

1. Pola Perlindungan Hukum Bagi Tenaga Kerja Lokal Dalam Sistim Outsourcing di Timor Leste Berdasarkan Ketentuan Hukum Indonesia dan Timor Leste

UU No. 13 Tahun 2003 tentang Ketenagakerjaan, secara eksplisit tidak mengenal istilah outsourcing. Pengertian outsourcing itu sendiri dapat dilihat dalam
Pasal 64 yang menyatakan bahwa perusahaan dapat menyerahkan sebagian pelaksanaan pekerjaannya kepada perusahaan lainnya melalui perjanjian pemborongan atau penyediaan jasa pekerja/ buruh yang dibuat secara tertulis.

Berdasarkan hasil penelitian diperoleh data bahwa dikenal 2 jenis tenaga kerja yang ada di TELIN ini, yakni local staff dan home staff. TELIN memberlakukan sistim outsourcing dengan memperkerjakan tenaga lokal Timor Leste yang disebut sebagai local staff. Penggunaan sistim outsourcing ini mengikuti ketentuan hukum di Indonesia yakni UU No. 13 Tahun 2003 tentang Ketenagakerjaan. Penggunaan sistim outsourcing tidak dilarang dalam Undang Undang Ketenagakerjaan Timor Leste. Praktik outsourcing yang dimaksud di dalam UU No. 13 Tahun 2003 ini dikenal dalam 2 bentuk, yaitu; pemborongan pekerjaan dan penyediaan pekerja/buruh sebagaimana diatur di dalam Pasal 65 dan Pasal 66. Memperhatikan 2 bentuk outsourcing tersebut pada dasarnya ada 2 bentuk outsourcing yang hendak diintrodusir oleh UU Ketenagakerjaan, di mana bentuk pertama adalah outsourcing pekerjaan (Pasal 65) dan bentuk ke dua outsourcing pekerja (Pasal 66). ${ }^{10}$

Uwiyono menilai outsourcing bentuk pertama dapat dipandang sebagai human trafficking (perdagangan manusia). Penilaian Uwiyono didasarkan pada asumsi bahwa dengan adanya perjanjian dimana perusahaan penyedia jasa tenaga kerja dan pengguna (user) menyerahkan sejumlah uang, maka seolah-olah terjadi penjualan tenaga kerja. Sementara itu, untuk jenis ke dua, Uwiyono berpendapat bahwa hal itu tidak terjadi human trafficking atau perdagangan manusia. Menurutnya, dalam bentuk yang ke dua ini, pekerja/buruh tetap memiliki hubungan kerja dengan perusahaan pemborong. Hubungan yang tercipta antara user dengan perusahaan pemborong hanya terkait dengan pekerjaan yang diborongkan tersebut. ${ }^{11}$ Sementara itu UU No. 4 Tahun 2012 di Timor Leste tidak mengatur secara jelas tentang outsourcing.

Bila dicermati lebih jauh adanya sistim

9. Depnakerstrans, tersedia di website http:/www.nakertrans.go.id, diakses pada tanggal 17 Mei 2015.

10. Aloysius Uwiyono, 2010, Outsourcing dan Permasalahannya di Indonesia, Yogyakarta, Genta Publishing, hlm 37.

11. Tempo.news, tersedia di website http:www.tempointeraktif.com, diakses pada tanggal 17 Mei 2014. 
outsourcing yang diberlakukan oleh pihak TELIN Timor Leste pada dasarnya untuk menghindari tanggung jawab langsung antara pekerja/buruh dengan TELIN bila berkaitan dengan permasalahan ketenagakerjaan, terutama yang menyangkut perpanjangan kontrak kerja. Pihak pekerja/buruh tidak dapat langsung berhadapan dengan pihak TELIN karena tenaga kerja tersebut diperoleh dari pihak ketiga yang dikenal dengan istilah vendor. Pihak vendor yang mengadakan kontrak dengan TELIN. Kemudian TELIN menggunakan tenaga kerja tersebut.

UU No. 13 Tahun 2003 membedakan antara usaha atau kegiatan pokok dan kegiatan penunjang. Ada persamaan antara bunyi undang undang tersebut dengan praktik industri, yaitu bahwa yang di-outsorce pada umumnya (tidak semuanya) adalah kegiatan penunjang (non core busines), sedangkan kegiatan pokok (core busines) pada umumnya (tidak semuanya) tetap dilakukan oleh perusahaan sendiri. Potensi masalah yang timbul adalah apakah pembuat dan penegak undang-undang di satu pihak dan para pengusaha dan industriawan di lain pihak, mempunyai pengertian dan interpretasi yang sama mengenai istilah-istilah tersebut. ${ }^{12}$ Dalam perusahaan TELIN, terdapat perbedaan yang jelas antara 3 jenis karyawan yang disesuaikan dengan ketentuan pengaturan karyawan di pusat (Jakarta) yakni: 1) local staff, yang terdiri dari tenaga kerja lokal sejumlah 110 orang; 2) home staff, karyawan Telkom (pegawai tetap) dan 3) ekspert yakni tenaga ahli/tenaga asing yang dibayar sesuai dengan tingkat keahliannya. Berkaitan dengan pemberlakukan sistim outsourcing, pihak TELIN hanya memberlakukan sistim outsourcing untuk tenaga kerja lokal atau local staff pada noncore Bussiness.

Adapun tenaga kerja yang dioutsorce pada TELIN mencakup 4 bidang yakni; driver, sales force, costumer service, dan call center officer. Ke empat bidang dalam bisnis TELIN termasuk dalam non core bussiness. Namun demikian bila dikaitkan dengan dengan pengelolaan tower dan Base Transceiver Station (BTS) termasuk dalam kategori core process dan support proces yang merupakan suatu core bussiness. Penempatan costumer care dan sales force dapat juga sebagai core bussiness karena berkaitan dengan sistim yang ada di TELIN namun demikian kenyataannya dalam bisnis TELIN, costumer care dan sales force merupakan non core bisnis.

Perbedaan antara core bussiness dan non core bussiness pada TELIN, berkaitan dengan proses produksi dan layanan costumer seperti price marketing, operation dan maintenance. Sementara itu proses pendukung adalah proses yang mendukung proses inti seperti IT \& application, billing \& operation, radio access network, corporate finance dan procurement \& general support..$^{13}$

Faktanya adalah bahwa perjanjian kerja antara karyawan dengan perusahaan outsourcing atau alih daya dapat berupa perjanjian waktu tertentu (PKWT) maupun perjanjian waktu tidak tertentu (PKWTT). Perjanjian kerja antara karyawan outsourcing dengan perusahaan outsourcing biasanya mengikuti jangka waktu perjanjian kerjasama antara perusahaan outsourcing dengan perusahaan pengguna jasa outsourcing. Hal ini dimaksudkan apabila perusahaan pengguna jasa outsourcing hendak mengakhiri kerjasamanya dengan perusahaan outsourcing, maka pada waktu yang bersamaan berakhir pula kontrak kerja sama antara karyawan dengan perusahaan outsourcing.

Karyawan outsourcing yang ditempatkan di perusahaan pengguna outsourcing tentunya secara aturan kerja dan disiplin kerja harus mengikuti ketentuan yang berlaku pada perusahaan pengguna outsourcing. Dalam perjanjian kerja sama antara perusahaan outsourcing dengan perusahaan pengguna outsourcing harus jelas dari awal, tentang ketentuan apa saja yang harus ditaati oleh karyawan outsourcing selama ditetapkan pada perusahaan pengguna outsourcing. Hal-hal yang tercantum dalam peraturan perusahaan pengguna outsourcing sebaiknya tidak diasumsikan untuk dilaksanakan secara total oleh karyawan outsourcing.

12. Jurnal hukum blogspot, tersedia di website http://jurnalhukum.blogspot.com, diakses pada tanggal 23 Nopember 13. 2013 . 


\section{Keberadaan Asas Keseimbangan Dalam Asas Kebebasan Berkontrak Pada TELIN di Timor Leste}

Pada dasarnya asas keseimbangan dalam konteks pembuatan kontrak tidak dapat dipisahkan dengan asas kebebasan berkontrak. Artinya, bahwa asas keseimbangan pada hakekatnya merupakan salah satu perwujudan dari asas kebebasan berkontrak yang dianut di dalam hukum kontrak. Sesuai dengan asas kebebasan berkontrak tersebut maka posisi atau kedudukan para pihak yang sepakat untuk membuat kontrak adalah sama dan seimbang.

Dari Kontrak yang berkode HK.05/FO-D00000/VI/2014, terutama yang berkaitan dengan ketentuan 2 tentang Durasi dan Data Kontrak Kerja, ternyata "Jangka waktu kontrak kerja dapat diakhiri sebelum masa berakhirnya berdasarkan evaluasi pemberi kerja". Evaluasi pemberian kerja dapat diartikan bahwa TELIN dapat mengakhiri hubungan kerja berdasarkan penilaian kerja TELIN sebagai pemberi kerja.

Namun demikian pemutusan hubungan kerja tanpa alasan dapat diartikan sebagai pemutusan hubungan kerja yang tidak adil. Pemutusan kerja yang tidak adil ini diatur di dalam Pasal 45 UU No. 4 Tahun 2012, yang merujuk pada Pasal 6 menyatakan bahwa:

Tidak seorangpun pekerja atau calon pekerja dapat secara langsung atau tidak langsung, diuntungkan atau dirugikan, dirampas haknya atau dikecualikan dari kewajibannya, atas dasar warna kulit, ras, status, jenis kelamin, warga negara, turunan atau etnis, posisi sosial atau kondisi ekonomis, pilihan dan keyakinan politik atau ideologi, agama, kelakuan dan kondisi fisik atau mental atau usia dan keadaan kesehatan.

Dari aspek kewenangan perusahaan, patut dapat diterima bahwa TELIN sebagai pemberi kerja memiliki kewenangan yang kuat untuk menentukan posisi si penerima kerja. Namun demikian, si penerima kerja sebagai pihak yang lemah dapat memenuhi prestasinya dengan itikad baik. Jadi dengan demikian akan tercipta posisi keseimbangan antara kedua pihak.
Asas keseimbangan dalam kontrak kerja mencakup dua bentuk, yakni asas keseimbangan sebagai asas etis dan asas keseimbangan sebagai asas yuridis. Asas keseimbangan sebagai asas etis mengandung arti adanya keadaan yang berat atau bobot pada kedua sisi adalah seimbang. Dalam keadaan inilah, keseimbangan yang merupakan "keadaan seimbang" karena adanya beberapa kekuatan yang tidak melampaui satu sama lain atau karena tidak adanya elemen yang menyebabkan terjadinya hal tersebut. ${ }^{14}$

Bila mencermati isi kontrak yang berkode HK.05/FO-D00000/VI/2014, terutama dalam hubungannya dengan kontrak baku, maka menurut Lenhoof dalam Johanes Gunawan, menyatakan bahwa kontrak baku adalah kontrak yang memiliki ciri-ciri antara lain "setiap "oferee" tidak memiliki posisi tawar (bargaining position) yang kuat, ia hanya mengikatkan diri pada kontrak atau menolak kontrak. ${ }^{15}$

Kontrak baku merupakan kontrak yang disediakan terlebih dahulu untuk digunakan secara umum dan penggunaannya berulangulang oleh salah satu pihak yang memiliki posisi yang lebih dominan. Penggunaan kontrak baku ini tanpa harus melalui proses negosiasi dengan pihak lawan. Apabila dilihat dari asas kebebasan berkontrak, pada dasarnya para pihak yang terlibat dalam suatu kontrak mempunyai kedudukan yang sama. Dengan kata lain, adanya keseimbangan dalam posisi tawar. Walaupun demikian dengan adanya kontrak baku, maka keberadaan asas kebebasan berkontrak dalam kebebasan pembuatan kontrak baku, merupakan sesuatu yang tidak berarti. Ini karena isi dan bentuk kontrak telah ditetapkan atau distandarisasi oleh pihak yang mempunyai kedudukan/posisi yang lebih dominan. Hal ini dapat dilihat pada kontrak yang berkode HK.05/FO-D00000/VI/2014 dimana kontrak tersebut telah disediakan oleh pihak TELIN dan pihak pekerja atau calon pekerja hanya menandatangani kontrak baku tersebut.

14. Herlin Budiono, 2003, Asas Keseimbangan Dalam Kebebasan Berkontrak, Bandung, Alumni, hlm 108.

15 Johanes Gunawan, 1999, Hukum Perlindungan Kosumen, Universitas Katholik Parahyangan Bandung, Program Pasca Sarjana Program Magister Ilmu Hukum, hlm 30. 


\section{Pola Penyelesaian Perselihan Perburuhan pada TELIN Timor Leste \\ Dalam pelaksanaan outsourcing atau} alih daya berbagai potensi perselisihan mungkin timbul, misalnya berupa pelanggaran peraturan perusahaan oleh karyawan maupun adanya perselisihan antara karyawan outsource dengan karyawan lain. Menurut Pasal 66 ayat (2) huruf c UU No.13 Tahun 2003, penyelesaian perselisihan yang timbul menjadi tanggung jawab perusahaan penyedia jasa pekerja. Jadi walaupun yang dilanggar oleh karyawan outsource adalah peraturan perusahaan pemberi pekerjaan, yang berwenang menyelesaikan perselisihan tersebut adalah perusahaan penyedia jasa pekerja.

Perusahaan outsource harus bisa menempatkan diri dan bersikap bijaksana agar bisa mengakomodir kepentingan karyawan, maupun perusahaan pengguna jasa pekerja, mengingat perusahaan pengguna jasa pekerja sebenarnya adalah pihak yang lebih mengetahui keseharian performa karyawan, dari pada perusahaan outsource itu sendiri. Ada baiknya perusahaan outsource secara berkala mengirim perwakilannya untuk memantau para karyawannya di perusahaan pengguna jasa pekerja sehingga potensi konflik bisa dihindari dan peforma kerja para karyawan bisa terpantau dengan baik.

Dalam UU No. 4 Tahun 2012, secara tegas menetapkan prinsip-prinsip utama dalam penyelesaian konflik perburuhan. Prinsip itikad baik bagi para pihak untuk menyelesaikan persoalan ini secara baik dan benar. Itikad baik merupakan kebutuhan utama, dimana tanpa itikad yang baik, persoalan yang akan diselesaikan justru akan menimbulkan soal lain yang baru. Selanjutnya, adanya suatu kewajiban bagi lembaga yang menyelesaikan persoalan perburuhan ini, mengedepankan prinsip impartialitas, independen dan keadilan. Ketiga prinsip ini merupakan citra peradilan modern. Adapun lembaga yang ditetapkan oleh undang-undang untuk menyelesaikan perselisihan perburuhan di Timor Leste adalah Dewan Arbitrase Tenaga Kerja, sebagai bentuk lain dari penyelesaian di luar pengadilan. Dalam penyelesian perselisihan ini maka ada cara atau proses ke arah sama melalui jalan konsiliasi dan mediasi.
Arbitrase merupakan pilah akhir jika ingin menyelesaikan perselisihan perburuhan yang bersifat non-litigasi. Hal ini berarti, perundang-undangan Timor leste menghendaki agar kebebasan berkontrak dalam penyelesaian perselisihan oleh para pihak yang berkontrak, perlu mendapat penghormatan yang memadai.

Catatan lain yang dikehendaki oleh UU No. 4 Tahun 2012 tentang Ketenagakerjaan adalah bahwa penyelesaian di luar pengadilan merupakan pilihan utama, sedangkan penyelesaian melalui jalur pengadilan merupakan pilihan yang terakhir, bila jalan yang lain yang telah disebutkan di atas telah mengalami jalan buntu.

Berkaitan dengan penyelesaian yang bersifat individual di lingkungan kerja, penggunaan arbitrase harus bersifat sukarela dan dimungkinkan bila pihak lain pula memberikan persetujuan. Artinya bahwa, aspek kompromi merupakan jalan tengah cara damai yang dapat dipilih agar dapat meredam konflik. Dalam catatan notifikasi dimaksud, para pihak perlu menyatakan kesedian atau ketidaksediaan untuk menerima penyelesaian melalui lembaga arbitrase. Namun hal yang demikian berbeda dengan perselisihan kolektif yang dapat dimintakan secara langsung ke Dewan Tenaga Kerja (Pasal 97 ayat (4) dan (5)).

Pola penyelesaian perburuhan menurut UU No. 13 Tahun 2003 diserahkan kepada Lembaga Penyelesaian Perselisihan Hubungan Industrial (Pasal 158) agar mendapat penetapan tentang hak yang harus diperoleh buruh/pekerja. Apabila penyelesaian melalui lembaga ini, tidak diterima oleh buruh, terutama dalam hal pemutusan hubungan kerja tersebut, maka berdasarkan Pasal 171 maka buruh dapat mengajukan gugatan ke Lembaga Penyelesaian Perselisihan Hubungan Industrial, paling lama 1 tahun sejak tangga dilakukan pemutusan hubungan kerjanya.

\section{Simpulan}

Berdasarkan uraian di atas dapat disimpulkan sebagai berikut: (1). Pola perlindungan tenaga kerja lokal yang menggunakan sistim outsourcing belum memadai karena baik UU Timor Leste No. 4 Tahun 2012 jo UU No.13 Tahun 2003 
tentang Ketenagakerjaan tidak mengatur secara jelas tentang outsourcing; (2). Dalam pembuatan kontrak baku, asas kebebasan berkontrak yang mengandung asas keseimbangan telah dibatasi ruang geraknya; (3). Menurut UU No.13 Tahun 2003 jika terjadi sengketa di TELIN maka kasus akan diserahkan kepada Lembaga Penyelesaian Perselisihan Hubungan Industrial (Pasal 158). Apabila penyelesaian melalui lembaga ini tidak berhasil maka berdasarkan Pasal 171, buruh dapat mengajukan gugatan ke Lembaga Penyelesaian Perselisihan Hubungan Industrial, paling lama 1 tahun sejak tanggal dilakukan pemutusan hubungan kerjanya. Saran dari hasil penelitian ini adalah: (a). penerapan sistim outsourcing di TELIN sebaiknya dihilangkan karena meniadakan aspek kemanusiaan yang bisa diartikan sebagai perdagangan manusia (human trafickking); (b). penetapan kontrak baku dalam perjanjian kontrak harus mengandung asas keseimbangan dalam asas kebebasan berkontrak; (c). pola penyelesaian perselesihan perburuhan pada TELIN seharusnya mengedepankan asas keadilan dan prinsip win-win solution melalui lembaga mediasi.

\section{Daftar Pustaka}

Budiono Herlin, 2003, "Asas Keseimbangan Dalam Kebebasan Berkontrak" Bandung, Alumni.

Kansil C.S.T., 1983, Pengantar Hukum Dan Tata Hukum Indonesia, Jakarta, Balai Pustaka

Damanik Sehat, 2006, Outsourcing \& Perjanjian Kerja, Jakarta, DSS Publishing

Fuady Munir, 2001, Hukum Kontrak (Dari Sudut Pandang Hukum Bisnis), Bandung, Citra Aditya Bakti.

Gunawan Johanes, 1999 , Hukum Perlindungan Kosumen, Bandung, Universitas Katholik Parahyangan Program Pasca Sarjana Program Magister Ilmu Hukum.

Kremic Tibor, Oya Icmeli Tukel and Walter O. Rom, "Outsourcing Decision Support: A Survey Of Benefits, Risks, And Decision Factors", Research paper, Supply Chain Management: An
International Journal, Vol. 11, No. 6, 2006,pp. 467-482.

Panggabean RM, "Keabsahan Perjanjian dengan Klausul Baku", Jurnal Hukum, Vol. 17, No. 4, Oktober 2010, pp. $651-667$.

Setiawan R, 2003, Pokok Pokok Hukum Perikatan, Bandung, Bina Cipta

Subekti R., 2005, Pokok-Pokok Hukum Perdata, Jakarta, Intermasa.

Uwiyono Aloysius, 2010, "Outsourcing dan Permasalahannya di Indonesia" Yogyakarta, Genta Publishing.

Yohanes Saryono, 2013, Perbandingan Hukum, Kupang, Universitas Nusa Cendana.

Depnakerstrans, tersedia di website http:/www.nakertrans.go.id, diakses pada tanggal 17 Mei 2015

Jurnal hukum blogspot, tersedia di website http://jurnalhukum.blogspot.com, diakses pada tanggal 23 Nopember 2013.

Tempo.news, tersedia di website http:www. tempointeraktif.com, diakses pada tanggal 17 Mei 2014

Kitab Undang-undang Hukum Perdata.

Undang-Undang Timor Leste Nomor 04 Tahun 2012 tentang Ketenagakerjaan.

Undang-Undang Nomor 13 Tahun 2003 tentang Ketenagakerjaan 